\title{
Mentoring experience in medical residency: challenges and experiences
}

\author{
Experiência de mentoria na residência médica: desafios e vivências
}

\author{
Fernando Lima Lopes Filho' ${ }^{10} \mid$ flimalopesf@gmail.com \\ Francisco Vileimar Andrade de Azevedo' (1) vileimarandrade@gmail.com \\ Kristopherson Lustosa Augusto 2,3,4 (D) kristopherson@ufc.br \\ Hyvinna Suellen de Oliveira Silveira² (D) hyvinnasilveira@gmail.com \\ Fabrício André Martins da Costa ${ }^{1,2}$ (1) fabricioamc18@gmail.com \\ Karine Paschoal Botelho Alves ${ }^{1}$ (D) dermato@karinebotelho.com
}

\begin{abstract}
Introduction: Medical residency represents a challenging moment, with a high level of demand and the need to develop several personal and professional skills. Therefore, in April 2019, the unprecedented mentoring program for thirty internal medicine residents was implemented, seeking to offer personal support and encourage professional development.

Experience Report: A mentoring program was structured in April 2019, lasting 11 months, consisting of 30 internal medicine residents and 6 mentors with experience in clinical preceptorship, covering topics that are not usually discussed in the training of these specialists, such as professionalism, empathy, burnout and quality of life, time management, conflict management and role-model. The meetings took place monthly, in a location defined by the group. After the end of the activity, an opinion poll was conducted using a standardized questionnaire with answers arranged on a Likert scale to assess the relevance of the discussed topics and the impact on the medical residents' practice. A $90 \%$ response rate was obtained, highlighting the relevance of the topic Burnout and quality of life and empathy. A total of $96.3 \%$ of residents stated that the program changed their mind about their professional behavior. They declared that mentoring "opened their mind about the diversity of opinions, allowing personal and professional growth" and that "to manage time, conflicts, burnout are present in our daily lives and are also part of the medicine we practice". However, there were complaints about some difficulties among the group members to define the time and day when the meetings should be held. In summary, the activity had a positive evaluation from the mentees.

Discussion: There is a positive impact of the mentoring program on the training of a resident doctor, improving self-confidence and having a positive impact on the professional career despite the faced difficulties. Mentoring also serves as a psychosocial support, creating free access between the resident and the preceptor, culminating, based on our evaluation, in an excellent relationship between mentors and mentees.

Conclusion: In Ceará, the mentoring program for internal medicine residents was unprecedented. There is a positive effect, in which important topics were discussed in more depth, with greater personal and professional growth. We suggest that mentoring be maintained and included as an essential activity in the curriculum of Medical Residency Programs.
\end{abstract}

Keywords: Medical Education; Mentoring; Medical Residency.

\section{RESUMO}

Introdução: A residência médica representa um momento desafiador, com elevado nível de exigência e necessidade de desenvolvimento de inúmeras competências pessoais e profissionais. Com base nisso, implantou-se, em abril de 2019, um programa de mentoria inédito para 30 residentes de clínica médica, buscando oferecer suporte pessoal e estimular desenvolvimento profissional.

Relato de experiência: O programa de mentoria foi estruturado em abril de 2019, com 30 residentes de clínica médica e seis mentores com experiência em preceptoria clínica. Com duração de 11 meses, o programa abordou temas não usualmente discutidos na formação desses especialistas, como profissionalismo, empatia, burnout e qualidade de vida, gestão de tempo, gestão de conflitos e role-model. Os encontros ocorriam mensalmente, com local definido pelo grupo. Após o fim da atividade, foi realizada pesquisa de opinião utilizando questionário padronizado com respostas em escala Likert para avaliação de relevância dos temas discutidos e impacto na prática dos médicos residentes. Obtiveram-se $90 \%$ de respostas, nas quais se destacou a relevância dos temas burnout e qualidade de vida e empatia. Dos residentes, 96,3\% afirmaram que as discussões mudaram a forma deles de pensar e agir profissionalmente. Destacaram que o mentoring "abria a mente acerca de diversidade de opiniões, permitindo crescimento pessoal e profissional" e que "Gerir o tempo, conflitos, burnout estão presentes no nosso dia a dia e também fazem parte da medicina que praticamos", pontuando dificuldade de consenso entre os membros do grupo para definição do horário e dia a ser realizada a reunião. A atividade demonstrou avaliação positiva dos mentorados.

Discussão: Na formação de um médico residente, o programa de mentoria melhora a autoconfiança e promove um impacto positivo na carreira profissional apesar das dificuldades enfrentadas. A mentoria funciona ainda como suporte psicossocial, pois cria-se um livre acesso entre residente e preceptor, o que culmina, na nossa avaliação, em uma excelente relação entre mentores e mentorados.

Conclusão: No Ceará, o programa de mentoring para os residentes de clínica médica foi inédito. Houve efeito positivo, em que temas importantes foram discutidos com mais profundidade, com maior crescimento pessoal e profissional. Os autores sugerem que o mentoring seja mantido e incluído como atividade essencial no currículo dos programas de residência médica.

Palavras-chave: Educação Médica; Mentoria; Residência Médica.

${ }^{1}$ Hospital Geral Doutor Waldemar Alcântara, Fortaleza, Ceará, Brazil.

2 Universidade de Fortaleza, Fortaleza, Ceará, Brazil.

${ }^{3}$ Centro Universitário Christus, Fortaleza, Ceará, Brazil.

${ }^{4}$ Universidade Federal do Ceará, Fortaleza, Ceará, Brazil.

| Associate Editor: Izabel Cristina Meister Martins Coelho.

Received on 03/04/21; Accepted on 04/23/21. | Evaluated by double blind review process. 


\section{INTRODUCTION}

Medical residency represents a period with a high level of professional demand, being a unique and very challenging moment. Experiencing an environment with a high level of demand, the resident doctors must develop skills within their specialty, while dealing with several stress factors, such as a deficient public assistance system, extensive workload and sleep deprivation, which results in losses to their mental health, making them less able to provide adequate and safe care to patients ${ }^{1,2,4}$.

Therefore, tutoring programs, in the form of mentoring, have been proposed as a strategy to offer personal support and encourage the professional development of future specialists $^{1,2}$. In this teaching modality, there is an empathic relationship between the resident doctors, the mentees, and their mentor, an experienced doctor who assists in the different challenges throughout the training, representing a figure that inspires and guides ${ }^{4,5}$.

Mentoring programs promote personal growth and professional development to the mentee, aiming at addressing issues related to the medical career, psychosocial well-being and role-model. In a study assessing 24 medical schools, mentees showed significantly more professional satisfaction than those without mentors ${ }^{3}$. Moreover, mentoring has been strongly associated with better performance in specialty board certification exams in the United States ${ }^{2}$.

Therefore, the implementation of a medical training plan that combines the development of technical skills and specific knowledge with affective, social and ethical development, with close contact between mentor and mentee, will have a positive impact on the mental health of the resident doctor, contributing to the improvement of this professional's self-confidence, making them more confident to perform, including the role of a mentor, in the teaching-learning process for medical students and interns. That is how an institutional support network is structured ${ }^{1-4}$.

This report brings the unprecedented experience of a mentoring program developed for the Internal Medicine residency in a secondary hospital, located in the state of Ceará, Brazil, in which we describe the stages of its structuring and implementation, as we evaluate, through the application of a standardized questionnaire, the practical impacts of the topics and strategies discussed in the daily life of the medical resident.

\section{EXPERIENCE REPORT}

\section{Structuring, Implementation and Organization of the Mentoring Program}

In 2018, a group of preceptors participated in a mentoring workshop at a medical congress, when the idea of implementing a mentoring program in the medical residency arose. In April 2019, after a meeting between the Medical Residency Commission (COREME, Comissão de Residência Médica) and the Internal Medicine Residency Coordination, a mentoring program for thirty Internal Medicine residents, lasting 11 months, was implemented. A group of mentors was chosen according to the service preceptors' interest. After this choice, the group was trained on the mentoring technique, and this training was carried out with the collaboration of a team of medical mentors, previously experienced in a university hospital from another state. The training was carried out through videoconference meetings, in which a team of preceptors reported their mentoring experiences during the medical residency and transmitted some theoretical concepts and practical notions for the method organization.

The group of mentors then defined that 'Mentoring' should be structured in groups consisting of one mentor and five mentees. Thus the mentor should invariably be a doctor with experience in Internal Medicine preceptorship, in addition to being available to hold monthly meetings. It was essential that the mentors have characteristics such as empathy, spirit of leadership and desire to share their experiences with the group of mentees, contributing to their personal and professional evolution. As for the mentees, they must be Internal Medicine residents, which is related of the first and second years of specialization.

The topics to be discussed were previously defined by the residency mentors and coordinators, namely: professionalism, burnout and quality of life, empathy, role model, conflict management and time management.

Each topic should be introduced by the mentor; however, two mentees would be in charge of having a greater theoretical basis for the topic being discussed, with scientific references. The mentor initially presented some questions at the start of the meeting, which later took place freely, as the mentees desired or manifested.

The meetings took place monthly, and the activity was categorized as a priority and mandatory within the medical residency workload. The place and time was jointly defined by the group based on the interests of its members, with several meetings taking place in areas outside the hospital environment, so there was an atmosphere of greater relaxation, such as restaurants or cafes. The activity lasted two hours. During the discussion, questioning and reflections were generated and debated together, creating an environment in which residents could speak freely, safely, without demands caused by their professional routine.

\section{Mentees' Feedlback}

At the end of the activity, in February 2020, an opinion poll was carried out on the topics discussed with all the mentees 
using a standardized questionnaire with answers arranged on a six-point Likert scale (0 to 5), with categorized answers ranging from "I totally agree" to"I totally disagree", using the Google Forms platform, anonymously. Questions were developed to assess how important the discussed topics were and the answers were graded on a 6- point scale, from 0 to 5 , with 0 being considered "not important" and 4 and 5 as "very important".

To understand the relevance of the mentoring program for each resident, the questionnaire contained the following questions: "Were the discussed topics relevant to your professional practice?", "Did the mentoring program change your professional medical/resident conduct?" and "Which of the chosen topics had the greatest potential for change in your performance as a health professional?". Each resident was also asked to suggest a topic to constitute the discussions, as well as which improvements could be implemented to improve the activity structure and dynamics. We received $90 \%$ of responses to the questionnaire, a total of 27 residents $(n=30)$.

A quantitative analysis shows that $44.4 \%$ of residents totally agreed that the developed discussions changed their way of thinking and acting as professionals, while $51.9 \%$ partially agreed. When we analyzed this result qualitatively, asking them to justify their positions, we obtained several positive evaluations:

"They help to open your mind to issues that we do not usually take the time to discuss and that are essential to our routine as doctors and as persons."

"Discussing mentoring topics opened our minds about different opinions and allowed us to grow personally and professionally, in addition to helping to embrace and feel embraced in our difficulties."

"The discussions covered topics that are part of medical practice, but that they do not teach us in medical school. Managing time, conflicts, and burnout are present in our daily lives and are also part of the medicine we practice. Talking about others and listening to their conflicts teaches us to better address these problems on a daily basis"

"Mentoring allowed residents to be placed, in the presence of their staff, in a horizontal position, thus allowing them at that moment, to position themselves in a more free and natural way, enabling important, but usually not developed topics, to be treated in depth and naturally. This resulted in a large part of what was discussed to be apprehended."

Some residents mentioned negative points:

"Over time, and the difficulties of everyday life, the discussed ideas are not very feasible".

Moreover, it is also mentioned that
"The groups are heterogeneous due to the mentor's difference. Maybe try to standardize to a minimum of activities so that the experience between the residents is not so different".

In addition, when asked about a specific change in conduct as a resident doctor related to some aspect, $81.4 \%$ agreed that there was an impact (37\% totally and $44.4 \%$ partially). When asked about the relevance of the topics proposed for discussion, $96.3 \%$ agreed that they are relevant to medical practice.

Regarding the most relevant topics for the meetings, Burnout was the topic of greatest impact for the mentees in terms of modifying the field of practice, receiving scores four and five by $77.8 \%$ of the resident doctors, of which $51.9 \%$ gave the maximum score and $25.9 \%$ gave a score of four.

Immediately afterwards, the Empathy topic was the second most relevant one, with a percentage of $70.3 \%(40.7 \%$ gave a score of four and $29.6 \%$ gave the maximum score). Conflict Management was relevant and a practice modifier for $66.6 \%$ of the residents, followed by Professionalism, with $59.3 \%$ of positive evaluation, Time Management, with $51.9 \%$ and RoleModel, showing $48.1 \%$ ( Table 1 ).

Among the topics suggested for inclusion in the mentoring program in 2021, Financial Education stands out, mentioned by $35 \%$ of residents $(n=14)$. The following were also mentioned: "How to define your subspecialty", "Interpersonal relationship and leadership", "Interpersonal relationship with the multidisciplinary team", "Patient's Experience Evaluation" and "The role of the resident doctor in facing the pandemic".

Improvement points were requested from the mentees, and it was pointed out that: "Changing the mentoring group more than once, to have contact with more preceptors and other colleagues" would be positive, as well as welcoming "Residents from other specialties, to evaluate the viewpoint of each specialty on these issues", as a way of aggregating and diversifying the

Table 1. Which of the discussed topics had the greatest potential for change in your performance as a health professional?

\begin{tabular}{cc}
\hline Relevant Topics & \% (4-5) \\
\hline Burnout and Quality of Life & $77.8 \%$ \\
Empathy & $70.3 \%$ \\
Conflict management & $66.6 \%$ \\
Professionalism & $59.3 \%$ \\
Time management & $51.9 \%$ \\
Role-Model & $48.1 \%$ \\
\hline
\end{tabular}


view of the proposed topics. Moreover, it was suggested, since it was scored as a negative point, the difficulty of reaching a consensus regarding the time to hold the meetings, so that the activity could be "scheduled in advance". Another suggestion was to "include it into the 60-hour workload of the residency", since some mentors and mentees held meetings at times that exceeded the recommended workload.

\section{DISCUSSION}

By evaluating the mentees' feedback related to the structuring of topics and the activity itself, as well as the practical relevance of what was discussed, we demonstrated there is a positive impact on the resident doctor's training. When addressing topics that are not usually discussed during undergraduate school training and that are invariably part of a trained professional's life, it was perceived that there is a change of conduct in the field of practice, resulting in beneficial reflections ${ }^{5}$.

Mentoring programs were associated to the improvement in self-confidence, with a long-term impact on professional careers, with reports of observational studies carried out in England of improved results in the annual performance assessment and competency progression tests, with $86.4 \%$ of these mentees significantly reaching maximum scores ${ }^{5}$.

In addition to the performance, we realized that the most relevant topic for the program residents was Burnout and quality of life. There is a prevalence of approximately $40 \%$ of professional burnout syndrome among doctors and residents, with negative consequences for these professionals' mental health. Medical residency, due to its structure and operation characteristics, increases the risk of mental problems related to this syndrome $e^{6,8}$. Therefore, with the association of mentoring programs to the possibility of psychosocial support, with the creation of an environment of free access between the resident and the preceptor ${ }^{4}$, we realize the importance of the activity in the context of a young doctor within their specialty, as mentioned by one of the residents :

"Talking about and listening to the conflicts of others teaches us to better address these problems on a daily basis".

Mentoring, even during medical residency, promotes the development of professionalism ${ }^{4,7}$. In a satisfaction pool carried out in a North American mentoring program for Internal Medicine residents, $70 \%$ of the participants reported that mentoring was important for their professional development ${ }^{4}$, similar to what was observed in our questionnaire ${ }^{2}$.

According to the report by RAMANAN et al, when asked about difficulties that could be encountered by residents who were not part of mentoring programs, 37\% of the residents reported being afraid of approaching a preceptor to question topics discussed in mentoring, while $28 \%$ reported that they did not have someone they could trust ${ }^{4,5,10}$. However, as mentees, 52\% answered that they had a significant personal relationship with their mentor ${ }^{4}$. Therefore, one of the positive aspects of the activity is precisely to promote the proximity between apprentice and teacher, since medicine, historically, is taught by the most experienced professional. In our assessment and based on the answers to our questionnaire, we understand that there was a positive association between mentors and mentees ${ }^{5,9}$.

We had some limitations in performing the activity, such as difficulty in defining the time to hold the meetings in a consensual way, with the occurrence at several times, at night, of an extrapolation of what was recommended as the ideal workload for the residency. Moreover, the heterogeneity of some groups, as mentioned in our questionnaire, may be the result of the difficulty in standardizing the introduction of the discussed topics by the mentors, which is a point to be improved for the next classes during the training.

\section{CONCLUSION}

In Ceará, the mentoring program for Internal Medicine residents was unprecedented. According to the answers to the questionnaire, we found a positive effect of the program on the mentees, in which topics equally important for medical education were discussed in more depth, allowing greater personal and professional growth. In view of this experience, the authors suggest that mentoring be maintained and included as an essential activity in the curriculum of Medical Residency programs.

\section{AUTHOR'S CONTRIBUTION}

Fernando Lima Lopes Filho participated in the writing, editing, and formatting of the manuscript and collection of the questionnaire data. Francisco Vileimar Andrade de Azevedo participated in the review of the manuscript and in the creation of the questionnaire. Kristopherson Lustosa Augusto participated in the design and review of the manuscript. Hyvinna Suellen de Oliveira Silveira participated in the formatting of the manuscript. Fabrício André Martins da Costa participated in the project design and the review of the manuscript. Karine Paschoal Botelho Alves participated in the manuscript editing, and by providing and supervising the references and manuscript review.

\section{CONFLICTS OF INTEREST}

The authors declare no conflicts of interest. 


\section{SOURCES OF FUNDING}

\section{The authors declare no sources of funding.}

\section{REFERENCES}

1. Moreira SNT, Albuquerque ICS, Pinto Junior FEL, Gomes AHB. Programa de Mentoria do curso de Medicina da Universidade Federal do Rio Grande do Norte: atividades integrativas em foco. Rev Bras Educ Med. 2020;44(4):e169. doi: 10.1590/1981-5271v44.4-20200103.

2. Akinla $\mathrm{O}$, Hagan $\mathrm{P}$, Atiomo W. A systematic review of the literature describing the outcomes of near-peer mentoring programs for first year medical students. BMC Med Educ. 2018.18(1):98. doi: 10.1186/s12909018-1195-1.

3. Henry-Noel N, Bishop M, Gwede CK, Petkova E, Szumacher E. Mentorship in medicine and other health professions. J Cancer Educ. 2019;34(4):62937. doi: 10.1007/s13187-018-1360-6.

4. Ramanan RA, Phillips RS, Davis RB, Taylor WC. Mentoring matters. Mentoring and career preparation in internal medicine residency training. $J$ Gen Intern Med. 2006;21(4):340-5. doi: 10.1111/j.1525-1497.2006.00346.x.

5. Ong J, Swift C, Magill N, Ong S, Day A, Al-Naeeb Y, et al. The association between mentoring and training outcomes in junior doctors in medicine: an observational study. BMJ Open. 2018;8(9):e020721. doi: 10.1136/ bmjopen-2017-020721.
6. Dyrbye LN, Burke SE, Hardeman RR, Herrin J, Wittlin NM, Yeazel M, et al. Association of clini-cal specialty with symptoms of burnout and regret among US resident physicians. JAMA Netw Open. 2018;320(11):1114-30. doi: 10.1001/jama.2018.12615.

7. Ortega G, Smith C, Pichardo MS, Ramirez A, Soto-Greene M, Sánchez JP. Preparing for an academic career: the significance of mentoring. MedEdPORTAL. 2018;14:10690. doi: 10.15766/mep_2374-8265.10690.

8. Moreira SNT, Vasconcellos RLSS, Heath N. Estresse na formação médica: como lidar com essa realidade? Rev Bras Educ Med. 2015;39(4):558-64. doi: 10.1590/1981-52712015v39n4e03072014.

9. Martins AF, Bellodi PL. Mentoring: uma vivência de humanização e desenvolvimento no curso médico. Interface Comun Saúde Educ. 2016;20(58):715-26. doi: 10.1590/1807-57622015.0432.

10. Cameron D, Dromerick LJ, Ahn J, Dromerick AW. Executive/life coaching for first year medi-cal students: a prospective study. BMC Med Educ. 2019;19(1):163. doi: 10.1186/s12909-019-1564-4. 